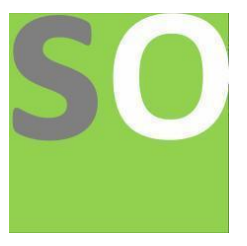

Article title: SWOT Analysis of Solar Pumping Finance Fund (PV Fund)

Authors: Ahmed Abdalla[1]

Affiliations: Omdurman Islamic University, Khartoum, Sudan[1]

Orcid ids: 0000-0002-4731-9065[1]

Contact e-mail: iahmedabusin@gmail.com

License information: This work has been published open access under Creative Commons Attribution License http://creativecommons.org/licenses/by/4.0/, which permits unrestricted use, distribution, and reproduction in any medium, provided the original work is properly cited. Conditions, terms of use and publishing policy can be found at https://www.scienceopen.com/.

Preprint statement: This article is a preprint and has not been peer-reviewed, under consideration and submitted to ScienceOpen Preprints for open peer review.

DOI: 10.14293/S2199-1006.1.SOR-.PPYRCQO.v1

Preprint first posted online: 11 August 2021

Keywords: Photovoltaic — solar water pumping - PV fund - SWOT 


\title{
SWOT Analysis of Solar Pumping Finance Fund (PV Fund)
}

\author{
Ahmed Elbashir Mohamed Abdalla, Mechanical Engineering, Omdurman Islamic \\ University, Khartoum, Sudan, iahmedabusin@gmail.com
}

\begin{abstract}
Sudan is a country with a great abundance of fertile and arable land as well as water resources. However, unstable Nile levels and seasonal rain limit agricultural spans in the year, and agricultural activities far from river banks make it necessary to use underground water. Photovoltaic water pumping systems have been available in Sudan from early times, however high up-front costs for initial investment contributed to halting widespread use of the systems. A recent project developed by the United Nations Development Program (UNDP) in Sudan, the PV fund, incentivizes the deployment of such systems for farmers by introducing a low-risk finance mechanism. This paper aims to conduct a Strengths, Weaknesses, Threats, and Opportunities (SWOT) analysis on this finance mechanism, and further propose recommendations and alternatives. The study concluded that the strengths are not requiring the beneficiary to provide any guarantees to obtain finance, solving the problem of high-cost PV pumping, distributing risks to the financiers, and attracting farmers and beneficiaries because the repayment period is 4 years. The weak point is the long-term operability. It also provides future opportunities for banks and financial institutions to finance the mechanisms of pumping water, which helps industrial and urban development. The main threats are the government, inflation, fluctuating exchange rates, and difficulty in pricing equipment.
\end{abstract}

\section{Keywords}

Photovoltaic — solar water pumping — PV fund — SWOT 


\section{INTRODUCTION}

Agriculture is an important sector in Sudan's economy, It's almost 30-35\% of the total GDP and a source of livelihood for about $65 \%$ of the population, $80 \%$ of Sudan's poor live in rural areas depending on agriculture directly or indirectly [1]. According to the World Bank, Sudan's population reached 40.23 million by the year 2015 [2]. Almost $33 \%$ of Sudan's 1.886 million $\mathrm{km}^{2}$ is suitable for agriculture.

The irrigation is primarily rain-fed most farmers depend on government-led large irrigation schemes. Electricity covers only 59\% of the population, the Urban population access to electricity $83.8 \%$, and the rural population by $47.1 \%$ only [3]. Also last year rural areas experienced a huge diesel shortage highly affected the diesel pumps used in farms.

Groundwater is more abundant than other seasonal resources during drought season when at least $80 \%$ of the population relies on groundwater for irrigation. Away from the Nile basin and other non-Nilotic river wells, groundwater is the only source of water. Available groundwater is 900 billion cubic meters (BCM), with an annual recharge of 1,563 BCM [4].

Sudan has an abundance of solar resources with average solar insolation ranging between $5.5 \mathrm{kWh} / \mathrm{m} 2 /$ day in January to $7 \mathrm{kWh} / \mathrm{m} 2 /$ day in April. The water table depth typically ranges around 40-140 $\mathrm{m}$ and varies based on nature and type of aquifer [5]. Yet solar pumping projects struggle with high upfront capital costs and limited end-user financing schemes [6].

In 2016 the ministry of water resources irrigation electricity (MWRIE) established Solar Water Pump (SWP) in Northern state the project is a 5- year-long project (2016 - 2021), with a total budget of USD 4.89 Million granted by the Global Environmental Facility (GEF) through United Nations Development Program (UNDP).

A similar project signed to start soon, the River Nile state project funded by The Korea International Cooperation Agency (KOICA) and UNDP with a total budget of 7 million USD. (UNDP) Also, The African Development Bank (AfDB) funded a similar project in Northern and West Kordofan state with 21.7 million USD [7].

The SWP in the Northern state implements the innovative National Solar Fund (PV Fund) in collaboration with the Central Bank of Sudan and MoEFP as a financing mechanism and other projects will follow. The (PV fund) is a big opportunity to sustain and scale solar pumping systems as the first end-user financing schemes in Sudan.

The solar pumping components: 


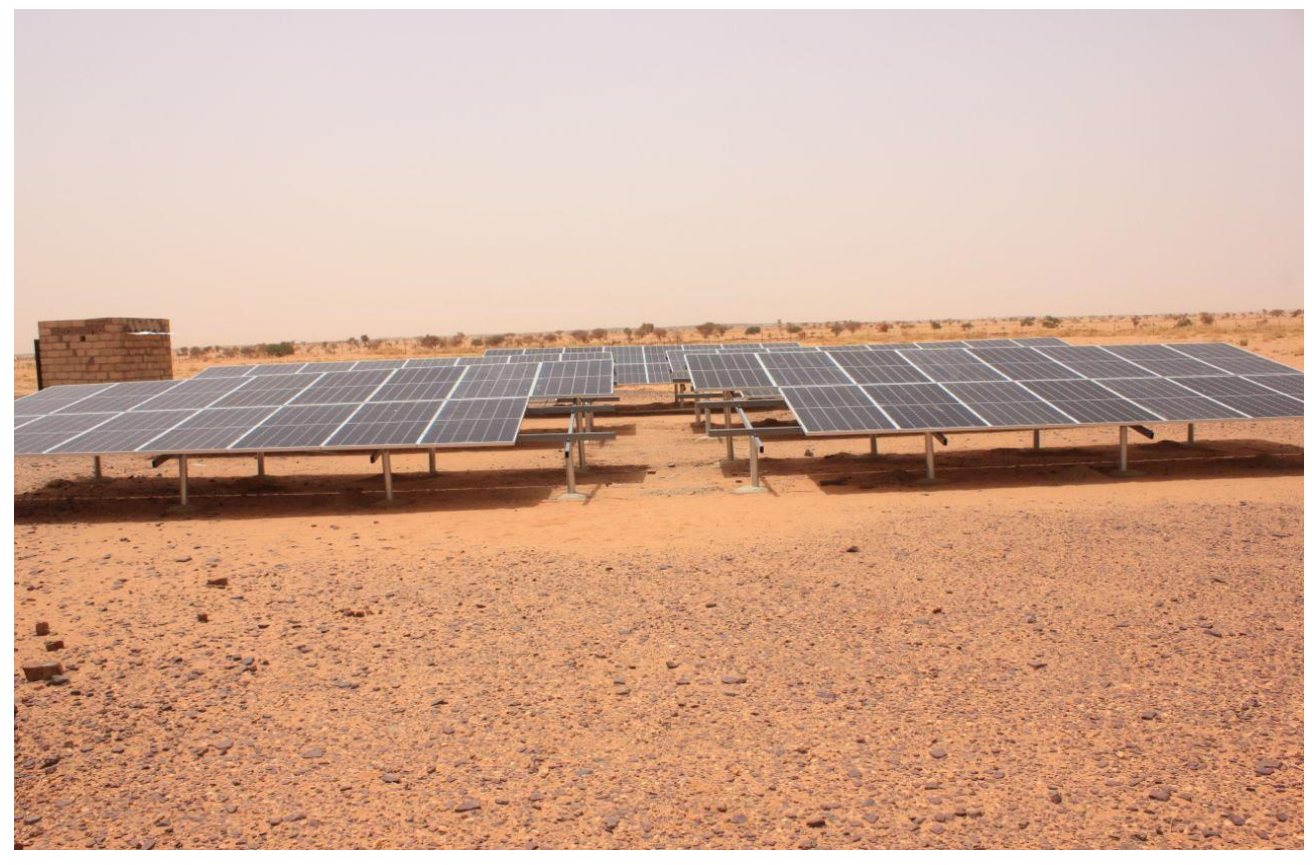

Figure 1. Solar arrays powering $30 \mathrm{HP}$ pump in west Omdurman.

\section{Solar Modules:}

Its assembly of photovoltaic cells generates direct current (DC) electricity from sunlight and a group of modules called an array.

Pump:

There are two types of pumps Submersible water pumps can be used to lift water from great depths of up to 200-meter-deep, Surface water pumps can be used to pump surface water of 3-6 meters deep.

\section{Mounting Structure:}

It's used to fix solar panels in different places such as roofs, or the ground. It's also could be a fixed structure or tracked structure.

Inverter or controller:

The controller is used to protect the pump from low or high voltage and the Inverter is used to convert the direct current generated from solar panels in to alternative current to operate the pump.

\section{METHODOLOGY}


Details regarding the steps to establish a PV fund project were obtained from interviews conducted with the PV fund project manager. The steps are as follows:

1. Management releases a tender for importers, suppliers, and project implementation.

2. Management places funds directed towards the project in a bank.

3. For the contractor to start implementation and start receiving funds, it has to acquire an insurance claim from the Ministry of Finance.

4. Farmers then apply to have a PV water pumping system installation, they are only liable for $25 \%$ of the total costs, which they pay in small installments after one year.

5. After one year, farmers start to pay installments quarterly for three years.

This paper aims at conducting a Strengths, Weaknesses, Opportunities, and Threats (SWOT), analysis, of this financing mechanism. SWOT analysis is mainly divided into two clusters, internal and external. The internal cluster addresses the strengths and weaknesses, while the external cluster addresses opportunities and threats.

\section{RESULTS AND DISCUSSION}

One important strength of this mechanism is that it doesn't require the beneficiary to submit any sort of collateral to acquire funding for the project, and therefore spares him any liability in the present or the future. It solves the fundamental problem of PV water pumping which is its high initiation cost and also distributes the risk for financiers by dividing the finance source among three different stakeholders. The mechanism is also attractive for the farmers and beneficiaries because the loan payment term extends over four years.

The key weakness to this mechanism is the issue of sustainability in the long run, partly from the internal structure that divides the finance burden among three different sources, and the fact that they already committed to this project over a finite period.

This mechanism also offers to arrange opportunities in the future. It paves the way for banks and financial institutions to develop similar mechanisms enabling and facilitating the sustainability of PV water pumping in Sudan, not only for agricultural projects but also for industrial and urban applications. This would therefore lead to another opportunity to increase awareness of eco-friendly and renewable energy sources both in local communities and in the industry and urban areas. Also, this project offers the chance to collect more comprehensive data for investment appraisals going towards farmers and small producers in the future. 
Finally, key threats to the mechanism are the government's turbulent commitment to the project and where it lies within its priorities, as well as the high inflation rates in the current time, and most importantly the varying foreign exchange rates and stakeholder's inability to agree on a defined mechanism for pricing inputs and rates to the implementation process, having most of the inputs being imported from abroad.

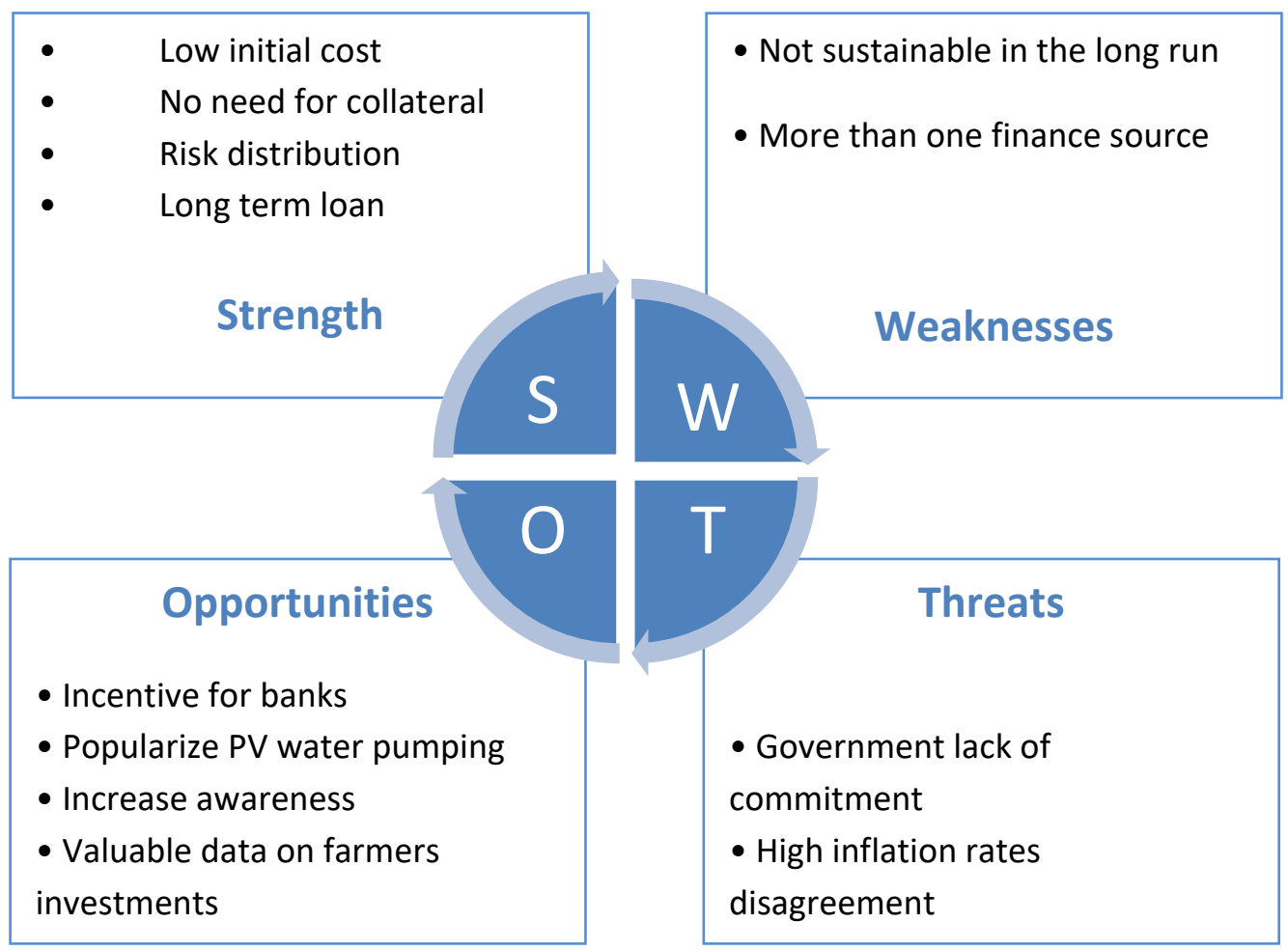

Figure 2. SWOT analysis of PV solar pumping project finance mechanism in Sudan (PV fund).

Sudan is considered one of the best countries for exploiting solar energy. It has an average annual amount of solar radiation of $(5.44 \mathrm{kWh} / \mathrm{m} 2-1$ day), sunshine duration is ranging from 8.5 to 11 hours per day, with a high level of solar radiation regime at an average of 20 to 25 (MJm-2 day-1) on the horizontal surface. This results in strategic benefits in replacing oil energy resources for environmentally friendly energy that helps to enhance development in rural areas, and its benefits extend from local to global. It provides opportunities for agricultural employment and leads to improving the living conditions of the population, which enhances efficiency and productivity and increases the savings of the beneficiaries. Renewable energy provides an opportunity for economic improvement by creating a market for producing companies and providing maintenance and repair services [8]. 
Distributed photovoltaic (PV) systems offer a great opportunity for larger integration and accessibility to energy, especially in rural areas. And while this alternative source of energy has seen a considerable decline in costs and proved to be a sound investment (Figure 3), the establishment of PV projects and its finance mechanisms present a challenging obstacle, since such systems require high up-front costs. In a recent study [9], researchers propose a case study for crowd-funding for PV water pumping systems in microgrids. Researchers carry out a SWOT analysis for a case of crowd-funding for a PV water pumping system in China. They identify key strengths as exceptional accessibility to investment and many environmental benefits key weaknesses as high administrative costs and fraud vulnerability, key opportunities as investment attractiveness and building an eco-aware society, and finally key threats as several legal constraints and regulatory uncertainty.

Mostly, solar panels have a lifespan of about 25-30 years. This does not mean that it will stop producing electricity, but its production decreases according to the manufacturers to a significant degree [10].

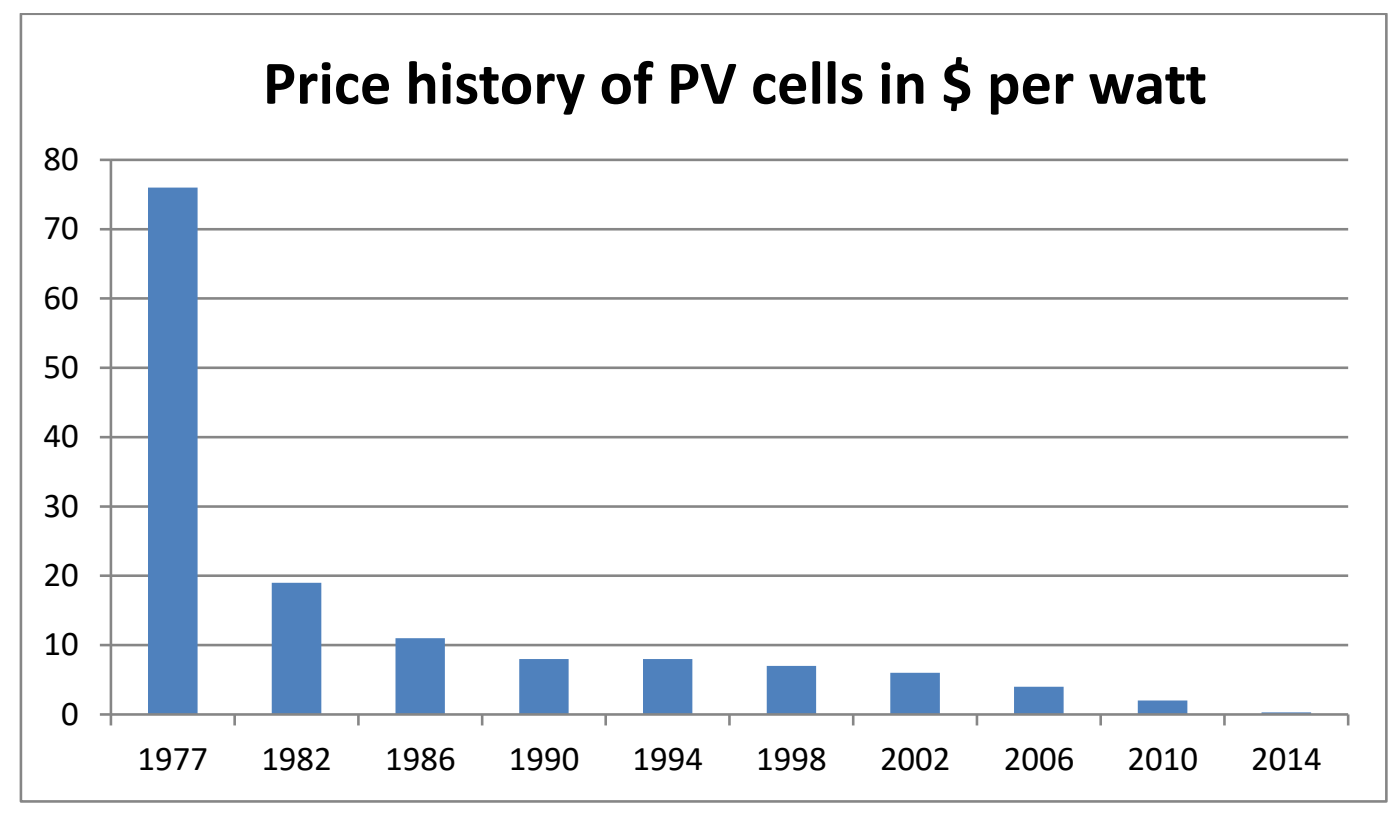

Figure 3. Shows the reduction in the price of silicon PV cells in USD per Watt. 


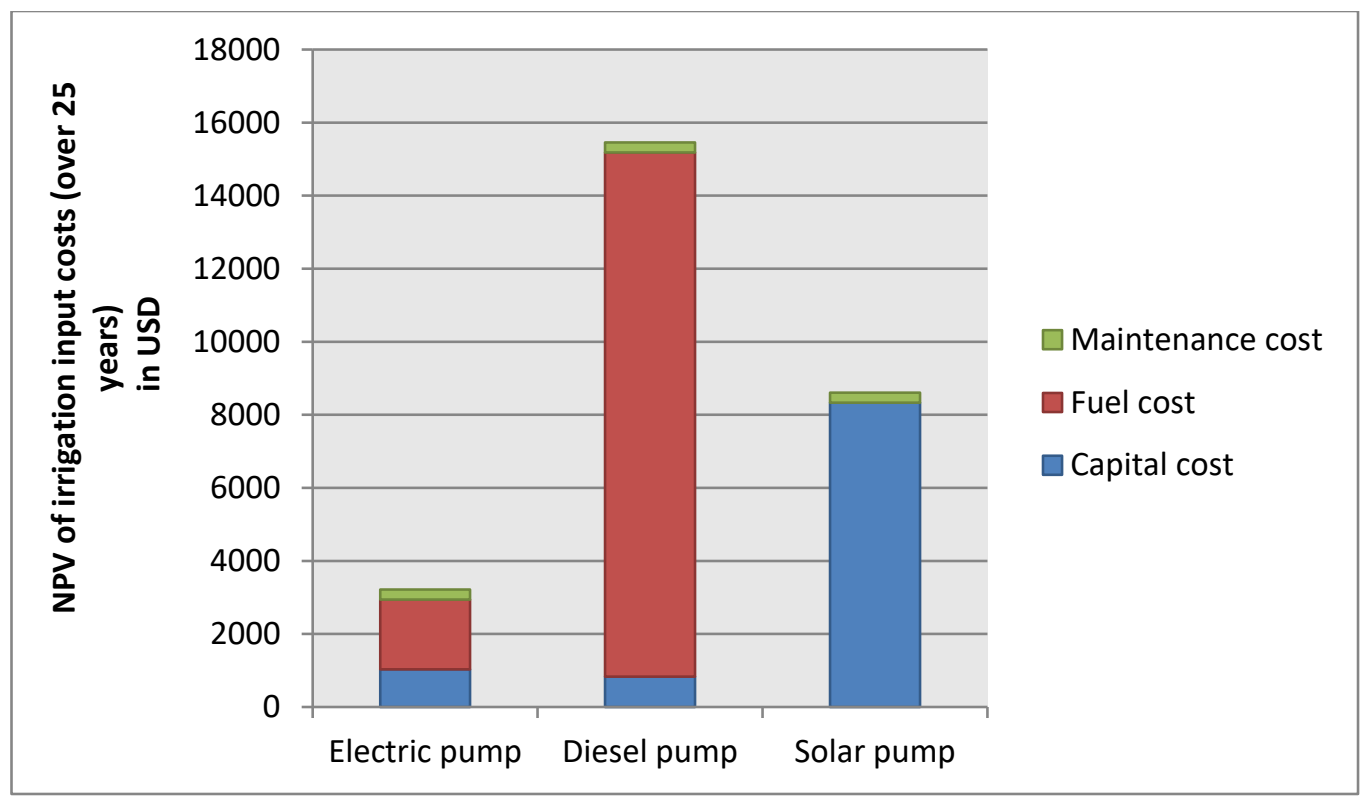

Figure 4. Compares irrigation cost for different alternatives.

Solar water pumps have high efficiency, it can flow up to $40 \mathrm{~m} 3 / \mathrm{H}$ with $200 \mathrm{~m}$ head. However, solar panels face problems, the most prominent of which is theft and vandalism, intentional and unintentional, and this constitutes a significant percentage in Sudan in particular. In addition to awareness of its importance and the great opportunities, it may provide to users, as well as the cost required to maintain it [10].

In another study [11], researchers evaluate different financing mechanisms for solarpowered irrigation systems, this time in India. Studying different finance mechanisms from self-ownership to water-as-a-service, researchers conduct interviews with a varied range of financiers and conclude the following recommendations and insights:

1. Limited awareness among bankers about the economic benefits of distributed solarpowered irrigation systems was impactful to raising the risk perceived by financiers.

2. Subsidies to water pumping systems are of paramount importance, however, if not streamlined properly cannot be sustainable in the long term and would otherwise have a negative impact.

3. Help provide financial institutions with information regarding investment appraisal and farmer's projected revenues and income.

4. It is vital to enhance confidence in long-term solar-powered irrigation systems as an investment.

5. It is essential to allocate efforts for larger water conservation and water resources schemes to make an investment in solar-powered irrigation systems more viable. 
6. Required future research on alternative delivery models such as water-as-a-service.

A recent project in Egypt for photovoltaic water pumping that was mainly developed by the European Bank for Reconstruction and Development and supported by the European Union, has thrived and managed to gather considerable financial support from regional and global financial institutions. A map of the stakeholders in the project and the financing mechanism is highlighted in Figure 5 [12].

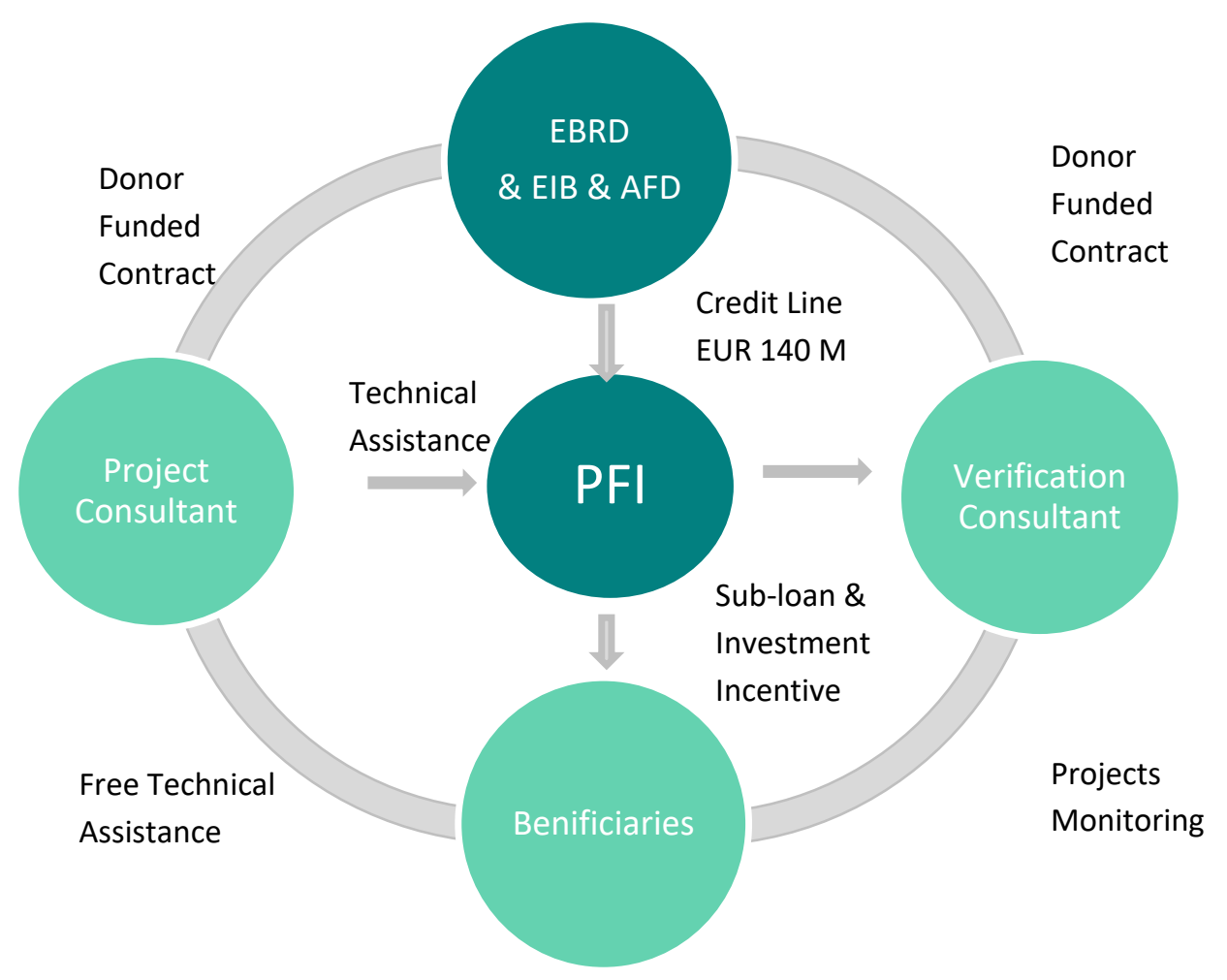

Figure 5. Egypt solar pumping project finance mechanism.

Locally, in 2016, the Ministry of Water Resources and Irrigation Electricity (MWRIE) established a solar water pump (SWP) in Northern State, the project was for a period of 5 years (2016-2021), with a total budget of $\$ 4.89$ million donated by the Global Environment Facility (GEF), Through the United Nations Development Program. The project was supposed to run on time, but it only lasted for one year, which represents the trial period for which direct funding from the project is available. The second-year was supposed to start in partnership with the Federal Ministry of Finance and the Ministry of Finance in the Northern State, but it was delayed. 
The financing mechanism for the PV fund projects is highlighted in Figure 6. The PV fund management deposits 25\% of the total costs, the State Ministry of Finance pays another $25 \%$ to be deducted from the State's development budget, and the Federal Ministry of Finance pays the remaining 50\%. The farmer, after four years, completes installments for the $25 \%$ he's entitled to pay, which would go back to the PV fund again, with the rest of the cost, $75 \%$, being government subsidies.

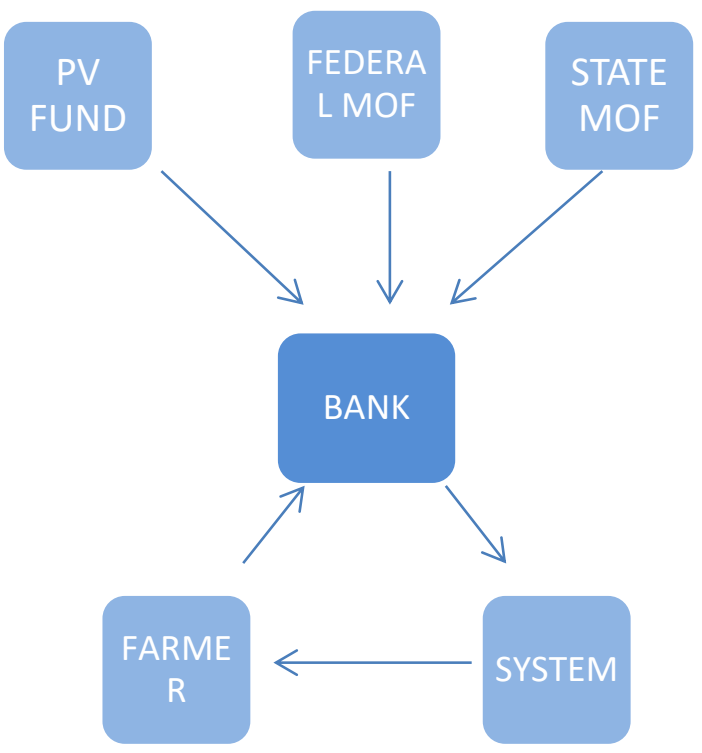

Figure 6. PV fund finance mechanism in Sudan.

\section{CONCLUSIONS}

This paper highlighted recent advances in financing mechanisms for PV water pumping in developing countries and conducted a SWOT analysis on the PV fund experience recently implemented in Sudan. Among strengths were ease of accessibility to finance and risk distribution, the weaknesses could be summarized as the model's lack of sustainability in the long run, while delivering opportunities for wider adoption of PV water pumping systems, and finally facing threats of uncertainty in stakeholder's commitment and agreement on pricing mechanisms citing inflation in the country. 


\section{RECOMMENDATIONS}

In light of this analysis, it is recommended that the finance source is unified, to ensure sustainability and commitment. While that would place more risk on the financing source, it would ensure that the projects are seamlessly implemented and sustained. Streamlining the subsidies from the government can also play a key role in promoting PV water pumping systems in different contexts. An alternative mechanism where banks pay for system supplies and implementation to farmers using these systems as collateral would also prove viable to the sustainability of the PV-fund.

\section{Acknowledgments}

The author would like to acknowledge the help of the PV fund project manager in Sudan, for providing the necessary information to carry out our research.

\section{REFERENCES}

[1] AfDB. "AfDB." https://www.afdb.org, 2020, https://www.afrik21.africa/en/sudanafdb-financessolar-irrigation-pump-project-in-sudan/. Accessed 3 November 2020.

[2] World Population Review, 2017. Sudan Population 2020 (Demographics, Maps, Graphs). [online] Worldpopulationreview.com. Available at: $<$ https://worldpopulationreview.com/countries/sudan-population> [Accessed 26 December 2020].

[3] Amankwah-Amoah, Joseph. "Solar Energy in Sub-Saharan Africa: The Challenges and Opportunities of Technological Leapfrogging." Thunderbird International Business Review, vol. 57, no. 1, 2015, pp. 15 - 31. https://thunderbird.asu.edu, https://onlinelibrary.wiley.com/doi/full/10.1002/tie.21677.

[4] International solar alliance. "0 Draft Pre-Feasibility Report for Implementation of Solar pumps in Sudan." isolaralliance.org/uploads/docs/ 34a8327c1ac32ef129458d6920f270.pdf. Accessed 3 November 2020.

UNDP,2019:sd.undp.org/content/sudan/en/home/presscenter /press releases/2019/UNDP-and-KOICA-Partner-in project-to-Promote-Solar-PoweredIrrigation-for sustainable-Agriculture-in-Sudan, Accessed November 3rd, 2020.

[6] United Nations Development Program. "United Nations Development Program." www.sd.undp.org/content/sudan/en /home/presscenter/pressreleases/2018/Scaling-upSolarEnergy-for-Agriculture-in-Sudan.html, Accessed 3 November 2020.

[7] The World Bank. "The World Bank." www.worldbank.org, 2016, https://www.worldbank.org/en/news/pressrelease/2016/05/16/ the-world-bank-group- 
and-Sudan's-ministry-of agriculture-launch-the-2016-enabling-the-business ofagriculture-report. Accessed 3 November 2020.

[8] Omer, Abdeen Mustafa. "Sustainable Development and Environmentally Friendly Energy Systems.” International Journal of Physical Sciences and Engineering, 2017, pp. 1-34., doi:10.21744/ijpse.v1i1.2.

[9] Zhang, C., Campana, P. E., Yang, J., Yan, J. (2016). Analysis of Distributed Photovoltaic Financing: A Case StudyApproachofCrowdfundingwithPhotovoltaicWaterPumpingSysteminMicrogrids.EnergyProcedia,103, 387393. https://doi.org/10.1016/j.egypro.2016.11.304

[10] The World Bank. Solar Water Pumping for Sustainable Water Supply [Internet]. World Bank. 2017 [cited 26 December 2020]. Available from: https://www.worldbank.org/en/topic/water/brief/solar-pumping

[11] Agrawal, S. and A. Jain. "Financing Solar for Irrigation in India Risks, Challenges, and Solutions." (2018).

[12] Workshop: GIZ/RE-ACTIVATE: Promoting Employment through Renewable Energy and Energy Efficiency in the MENA Region, Jose Luis Bobes, May 23, 2017. 